\title{
Articles
}

\section{Different Facets of Attitudes Towards Having Children: The Procreation Attitude Scale (PrAttS)}

\author{
Tristan Marhenke ${ }^{a}$, Roland Imhoff ${ }^{\star b}$
}

[a] Fresenius University of Applied Science Düsseldorf, Düsseldorf, Germany. [b] Department of Social and Forensic Psychology, Johannes Gutenberg Universität Mainz, Mainz, Germany.

\begin{abstract}
The attitudes towards children are more complex than simple positive/negative distinctions. In the present study, we sought in two studies $(\mathrm{N}=445)$ to provide a tool to explore different facets of attitudes towards babies and procreation by developing and validating a questionnaire regarding attitudes towards procreation. Study 1 was conducted to develop an English language scale tapping into adults' attitudes toward having offspring. A larger number of statements were formulated that expressed an emotional value and motivational attitudes towards having babies. The sample consisted of $n=157$ participants. Participants' responses were subjected to a preliminary principal components analysis with an oblique rotation. Study 1 obtained a relatively economical scale to tap into three facets of attitudes toward having children. Study 2 sought to validate a German language version of the same scale as in the previous study. A total of $n=$ 288 participants were recruited. The 13 items of the scale were subjected to a confirmatory factor analysis. Study 2 confirmed the threedimensional structure. The Procreation Attitude Scales (PrAttS) consists of 13 items representing three underlying dimensions: (1) unconditional positivity, (2) anticipated annoyance and (3) contingent willingness. The present investigations showed twice a gender difference in emotional attitudes, revealing that women have a stronger emotional interest in procreation and babies. The PrAttS provides an explicit method of interest for children, providing an alternative to more recently criticized implicit measures.
\end{abstract}

Keywords: children, attitudes, questionnaire, gender differences

Interpersona, 2020, Vol. 14(1), 69-83, https://doi.org/10.5964/ijpr.v14i1.3935

Received: 2019-12-27. Accepted: 2020-06-13. Published (VoR): 2020-07-02

*Corresponding author at: Department of Social and Forensic Psychology, Johannes Gutenberg Universität Mainz, Binger Str. 14-16, 55122, Mainz, Germany. E-mail: Roland.imhoff@uni-mainz.de

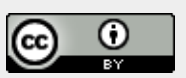

This is an open access article distributed under the terms of the Creative Commons Attribution 4.0 International License, CC BY 4.0 (https://creativecommons.org/licenses/by/4.0/), which permits unrestricted use, distribution, and reproduction in any medium, provided the original work is properly cited.

People differ in how positive they are towards children. However, these attitudes may be more complex than simple positive/negative distinctions (Lichtenstein \& Slovic, 2006). According to Liefbroer (2005), children fulfil needs in three categories: (a) economic reward, (b) emotional or psychological needs (such as self-development) and (c) social reward (such as a status gain). In Western societies, emotional and social benefits seem to be the core motives for deciding on children, while financial motives tend to reinforce a decision against having children (Liefbroer, 2005; Matias \& Fontaine, 2012; O'Laughlin \& Anderson, 2001). Bauer and Kneip (2013) found that attitudes of both partners played an equally important role in decision-making about the first child. Hutteman, Bleidorn, Penke, and Denissen (2013) found that personality traits of both partners were directly related to the fertility outcome. In particular, the self-confidence of both partners increased the likelihood of choosing a child, while aggressiveness in males reduced the likelihood of conceiving a child. Attitudes to children also greatly influence how (potential) partners are rated. Fiore and Donath (2005) were able to show 
that the perceived similarity in a romantic partner with regard to his or her desire to have children greatly influences his or her attractiveness. In the present work, an exploratory attempt was made to develop a scale that tracks different attitudes towards children and allows for a look at potential gender differences.

Parsons, Young, Kumari, Stein, and Kringelbach (2011) make one currently influential distinction regarding attitudes towards children. They investigated whether differences between emotional and motivational preference representations could be found using measures of conscious appraisal ('liking') and behavioral responsivity ('wanting') towards real-world infant and adult faces. Women gave significantly higher 'liking' ratings for infant faces (but not adult faces) than men did, but this difference was not apparent in the 'wanting' task, in which men and women could increase or decrease the duration for which they viewed an infant face. The authors suggested that infant faces may have similar motivational salience for men and women, despite gender differences in conscious ratings.

Despite the innovative potential of these findings, two aspects of this study deserve comment. First, the measures of wanting and liking did not only differ in their presumed motivational vs. emotional quality, but also their measurement modality. Second, the indicators of wanting were based on the interpretation of viewing times. Although a popular tool to assess preferences in many domains (e.g. Petterson, Dixson, Little, \& Vasey, 2018; Rosenzweig, 1942; Schmidt, Babchishin, \& Lehmann, 2017), the specificity of these measures has recently been questioned (Imhoff, Schmidt, Nordsiek, Luzar, Young, \& Banse, 2010; Imhoff, Schmidt, Weiß, Young, \& Banse, 2012). The present study thus sought to enhance the comparability of the different facets of attitudes towards babies by relying on the same modality (multi-item self-report items) across different sub-facets.

Despite the measurement issues, a fine-grained method might also help re-assess the existence of gender differences in the different aspect of baby-related attitudes. It has been repeatedly argued that women and men should differ in their attitudes towards babies, as cultural gender stereotypes expect women to be nurturing and affectionate towards babies and children to a greater extent than is the case for men (Katz-Wise, Priess, \& Hyde, 2010; Kaufman \& Uhlenberg, 2000). In other words, people suspect that outward emotional readiness for children, which has been shaped by societal expectations, is reflected in women having a higher emotional 'liking` of children (Parsons et al., 2011). Nevertheless, gender differences in responding to infants are far from definitive (Berman, 1980; Liu et al., 2015). Hildebrandt and Fitzgerald (1978) reported that women are generally more perceptive and responsive to cuteness than men are, but recent findings (Parsons et al., 2011) show that both men and women 'want' to view infants for similar durations, suggesting a more equal interest in infants than previously thought. In line with Parsons and colleagues (2011), the current study suspects the existence of gender differences in emotional attitudes ('liking') but not in motivational attitudes ('wanting').

In the present study, we sought to provide a tool to explore attitudes towards babies and procreation by developing and validating a questionnaire regarding attitudes towards procreation, the Procreation Attitude Scales (PrAttS). Both English and German versions were tested. The aim of this study, however, goes beyond this practical goal. As another goal, we examined whether gender differences in attitudes towards children and reproduction can be found using this measure. All materials can be found on OSF (see Supplementary Materials section). 


\section{Study 1}

An initial study was conducted to develop a scale tapping into adults' attitudes toward having offspring. A larger number of statements were formulated that expressed a general positive (e.g., I feel happy when I see children playing) or negative (e.g., Children are demanding) emotional value toward having babies. Items soliciting rational attitudes (such as "you should only have children when you have a secure job") reflecting motivational attitudes towards having babies were also formulated.

In an exploratory fashion, the study also assessed participants' orientation to long- and short-term relationships (Schwarz \& Hassebrauck, 2007) as well as their sociosexuality (Penke \& Asendorpf, 2008). Sociosexuality reflects differences in seeking sexual contact without a deeper emotional attachment. Extremely large gender effects are often reported with regard to sociosexuality (Penke \& Asendorpf, 2008; Schwarz \& Hassebrauck, 2007); especially in terms of interest in short-term relationships. For this reason, the present study explores whether these effects can be replicated and whether these can be meaningfully linked to differences in attitude towards babies and reproduction.

\section{Method}

\section{Sample}

The sample consisted of 157 participants: 57 women $\left(M_{\text {age }}=35.2\right.$ years, $\left.S D=12.5\right)$ and 93 men $\left(M_{\text {age }}=32.1\right.$ years, $S D=9.8)$; the majority of participants held at least a bachelor's degree $(55 \%)$. The sample was recruited via MTurk and took place online.

\section{The Procreation Attitude Scale}

Drawing on the conceptual background summarized in the introduction, the authors of the current study obtained input from a native English-speaker and generated a preliminary pool of 36 items that presented attitudes towards children. The complete list of items with the initial factor loadings is presented in Appendix. In order to ensure applicability to persons with and without children, all items referred to procreation generally; no items referred to respondents' own offspring. Respondents indicated their agreement on a scale ranging from 1 (strongly disagree) to 5 (strongly agree).

\section{Relationship Orientations}

The Mateship Orientation questionnaire (Schwarz \& Hassebrauck, 2007) is a tool primarily used to assess long- and short-term mate preferences. It consists of two subscales with seven items each: long-term mate preferences (e.g. "Warmth and comfort are necessary parts of a relationship") and short-term mate preferences (e.g. "If I could, I would have sex with as many people as possible"). Participants rated the items on a Likert scale ranging from 1 (I strongly agree) to 7 (I strongly disagree).

\section{Sociosexuality}

The revised Sociosexual Orientation Inventory (SOI-R) (Penke \& Asendorpf, 2008) was included to measure sociosexual orientation, which is defined as inter-individual differences in seeking sexual contact without a deeper emotional attachment. This scale includes three components of sociosexuality: past behavioral experiences, attitudes toward uncommitted sex, and sociosexual desire. 


\section{Results}

Data analyses were performed through SPSS version 24 software. Participants' responses on the Procreation Attitude Scales (PrAttS) items were subjected to a preliminary principal components analysis with an oblique rotation. Results revealed ten components with eigenvalues of 1.0 that together accounted for $65.12 \%$ of the variance. Three components had eigenvalues greater than 2.0; the pattern matrix and scree plot suggested three interpretable components, each containing multiple items. Items with loadings $\geq .60$ and without meaningful cross-loadings on a second factor $(\leq .20)$ were selected. Thirteen items fulfilled these criteria (Table 1) and the emerging factors can be described as unconditional positivity (e.g., "I'd be a good father / mother;" 5 items), anticipated annoyance (e.g., "Having a baby means less time for myself;" 4 items) and contingent willingness (e.g., "You should only have children once you've found the perfect partner"; 4 items).

Table 1

Items and Corresponding Factor Loadings of the PrAttS in Studies 1 and 2

\begin{tabular}{|c|c|c|c|c|c|c|}
\hline \multirow[b]{3}{*}{ PrAttS item } & \multicolumn{6}{|c|}{ Factor loadings } \\
\hline & \multicolumn{3}{|c|}{ Study 1} & \multicolumn{3}{|c|}{ Study 2} \\
\hline & 1 & 2 & 3 & 1 & 2 & 3 \\
\hline \multicolumn{7}{|l|}{ Factor A: Unconditional positivity } \\
\hline $\begin{array}{l}\text { I feel I am capable of looking after a child (Ich fühle mich in der Lage, mich um ein } \\
\text { Kind zu kümmern) }\end{array}$ & .86 & .03 & -.03 & .74 & -.17 & -.15 \\
\hline I'd be a good father/mother (Ich wäre ein guter Vater / Mutter) & .83 & -.06 & -.02 & .71 & .30 & -.09 \\
\hline $\begin{array}{l}\text { I can see myself having more than one child (Ich kann mir vorstellen auch mehrere } \\
\text { Kinder zu haben) }\end{array}$ & .75 & .01 & .04 & .70 & .35 & -.19 \\
\hline $\begin{array}{l}\text { Children require more love than I can give (Kinder brauchen mehr Liebe als ich } \\
\text { geben kann) (R) }\end{array}$ & .74 & -.03 & .13 & .64 & .10 & .31 \\
\hline $\begin{array}{l}\text { I feel happy when I see children playing (Ich fühle mich glücklich, wenn ich spielende } \\
\text { Kinder sehe) }\end{array}$ & .73 & -.05 & -.04 & 69 & -.02 & -.16 \\
\hline \multicolumn{7}{|l|}{ Factor B: Anticipated annoyance } \\
\hline $\begin{array}{l}\text { You must do without many freedoms when you have a child (Für ein Kind muss man } \\
\text { auf viele Freiheiten verzichten) }\end{array}$ & .03 & .84 & .04 & -.49 & .21 & .48 \\
\hline Bringing up children is difficult (Es ist schwierig Kinder zu erziehen) & .02 & .81 & .05 & -.07 & .08 & .44 \\
\hline Children are demanding (Kinder sind anstrengend) & -.10 & .78 & .20 & -.67 & .05 & .39 \\
\hline $\begin{array}{l}\text { Having a baby means less time for myself (Ein Baby zu haben bedeutet weniger Zeit } \\
\text { für mich) }\end{array}$ & -.03 & .75 & .16 & -.39 & -.01 & .44 \\
\hline \multicolumn{7}{|l|}{ Factor C: Contingent willingness } \\
\hline $\begin{array}{l}\text { You should only have children once you've found the perfect partner (Nur mit dem } \\
\text { perfekten Partner sollte man Kinder bekommen) }\end{array}$ & -.12 & .08 & .77 & .19 & .77 & .03 \\
\hline $\begin{array}{l}\text { You should only have children when you have a secure job (Man sollte erst Kinder } \\
\text { kriegen, wenn man einen sicheren Job hat) }\end{array}$ & .08 & .11 & .73 & -.27 & .55 & .14 \\
\hline $\begin{array}{l}\text { If you have a child, you need a partner who you can rely on (Wenn man ein Kind } \\
\text { bekommt, muss man sich auf seinen Partner verlassen können) }\end{array}$ & -.04 & .10 & .70 & .10 & .73 & .06 \\
\hline $\begin{array}{l}\text { You should only have children with someone who you have known for years (Kinder } \\
\text { sollte man nur mit jemandem bekommen, den man jahrelang kennt) }\end{array}$ & .16 & .10 & .70 & -.31 & .65 & .10 \\
\hline Eigenvalue & 3.14 & 3.03 & 1.71 & 4.12 & 2.33 & 1.44 \\
\hline$\%$ of variance & 24.22 & 23.23 & 13.15 & 29.43 & 16.65 & 10.27 \\
\hline
\end{tabular}

Note. Extraction method was principal axis factoring with a varimax rotation. German versions are in parentheses. $\mathrm{R}=\mathrm{Reverse}$ scored item. 
All resulting scales proved sufficiently reliable (Table 2). Unconditional positivity was strongly associated with an orientation toward long-term relationships. Anticipated annoyance was also significantly associated with this orientation. Contingent willingness was negatively related to positive attitudes towards promiscuous behavior and self-reported frequency of such behavior.

Table 2

Internal Consistency, Descriptive Statistics, and the Effect of Gender on Means of Study 1

\begin{tabular}{|c|c|c|c|c|c|c|c|c|c|c|c|c|c|c|c|}
\hline \multirow[b]{2}{*}{ Variable } & \multirow[b]{2}{*}{$\alpha$} & \multicolumn{3}{|c|}{ Women } & \multicolumn{3}{|c|}{ Men } & \multirow[b]{2}{*}{$t$} & \multicolumn{7}{|c|}{ Correlation $(n)$} \\
\hline & & $M$ & $n$ & $S D$ & $M$ & $n$ & $S D$ & & 1 & 2 & 3 & 4 & 5 & 6 & 7 \\
\hline $\begin{array}{l}\text { 1. Unconditional } \\
\text { positivity }\end{array}$ & .83 & 4.16 & 52 & 0.73 & 3.92 & 86 & 0.81 & $1.74^{*}$ & & & & & & & \\
\hline $\begin{array}{l}\text { 2. Contingent } \\
\text { willingness }\end{array}$ & .81 & 3.75 & 55 & 0.89 & 3.78 & 91 & 0.68 & -0.26 & $\begin{array}{c}-.06 \\
(139)\end{array}$ & & & & & & \\
\hline $\begin{array}{l}\text { 3. Anticipated } \\
\text { annoyance }\end{array}$ & .71 & 4.28 & 54 & 0.74 & 4.15 & 92 & 0.61 & 1.13 & $\begin{array}{r}.02 \\
(141)\end{array}$ & $\begin{array}{l}.31^{* *} \\
(148)\end{array}$ & & & & & \\
\hline $\begin{array}{l}\text { 4. Long-term mate } \\
\text { preference }\end{array}$ & .85 & 6.03 & 54 & 0.98 & 5.47 & 88 & 1.10 & $3.12^{* \star}$ & $\begin{array}{c}.74^{* *} \\
(134)\end{array}$ & $\begin{array}{c}.04 \\
(141)\end{array}$ & $\begin{array}{l}.21^{\star *} \\
(141)\end{array}$ & & & & \\
\hline $\begin{array}{l}\text { 5. Short-term mate } \\
\text { preference }\end{array}$ & .90 & 2.93 & 56 & 2.04 & 3.53 & 92 & 1.43 & $-6.60^{*}$ & $\begin{array}{c}.12 \\
(140)\end{array}$ & $\begin{array}{r}.15 \\
(148)\end{array}$ & $\begin{array}{l}-.07^{* *} \\
(148)\end{array}$ & $\begin{array}{l}-.26^{\star *} \\
(143)\end{array}$ & & & \\
\hline $\begin{array}{l}\text { 6. Past behavioral } \\
\text { experiences }\end{array}$ & .75 & 2.85 & 56 & 1.58 & 2.85 & 93 & 1.81 & -0.90 & $\begin{array}{r}.03 \\
(141)\end{array}$ & $\begin{array}{l}-.18^{\star *} \\
(149)\end{array}$ & $\begin{array}{c}-.08 \\
(149)\end{array}$ & $\begin{array}{c}-.04 \\
(144)\end{array}$ & $\begin{array}{l}.41^{* *} \\
(151)\end{array}$ & & \\
\hline $\begin{array}{l}\text { 7. Attitudes towards } \\
\text { uncommitted sex }\end{array}$ & .90 & 3.93 & 55 & 2.51 & 5.91 & 93 & 2.35 & $-4.85^{\star \star}$ & $\begin{array}{c}-.05 \\
(140)\end{array}$ & $\begin{array}{l}-.18^{\star *} \\
(148)\end{array}$ & $\begin{array}{c}-.11 \\
(149)\end{array}$ & $\begin{array}{l}-.19^{\star *} \\
(143)\end{array}$ & $\begin{array}{c}.78^{\star *} \\
(150)\end{array}$ & $\begin{array}{c}.55^{\star \star} \\
(151)\end{array}$ & \\
\hline 8. Sociosexual desire & .91 & 3.01 & 56 & 1.73 & 5.01 & 92 & 2.18 & $-5.84^{* *}$ & $\begin{array}{c}-.09 \\
(139)\end{array}$ & $\begin{array}{r}.08 \\
(147)\end{array}$ & $\begin{array}{c}-.01 \\
(147)\end{array}$ & $\begin{array}{l}-.21^{* *} \\
(142)\end{array}$ & $\begin{array}{c}.63^{* *} \\
(149)\end{array}$ & $\begin{array}{c}.43^{\star *} \\
(150)\end{array}$ & $\begin{array}{c}.61^{* *} \\
(149)\end{array}$ \\
\hline
\end{tabular}

${ }^{*} p<.10 .{ }^{* *} p<.05$.

There were also a number of gender differences. Unconditional positivity and the long-term mate preferences were significantly more pronounced among women. Men, on the other hand, reported a greater incidence of short-term mate preferences, more promiscuous attitudes toward uncommitted sex and a stronger sociosexual desire.

\section{Discussion}

Study 1 obtained a relatively economical scale to tap into three facets of attitudes toward having children: unconditional positivity, contingent willingness, and anticipated annoyance. Importantly, these attitudes are not only manifestations on one scale ranging from positive to negative but also (relatively) independent facets.

In line with Parsons and colleagues (2011), the study showed a gender difference in emotional attitudes ('Unconditional positivity"), revealing that women have a stronger emotional interest in procreation and babies. 
However, the study also showed that this gender difference disappears when the motivational attitude to procreation and babies ('Contingent willingness ') was measured.

The subjects in Study 1 are in a phase in which families are founded and children are conceived (Mathews \& Hamilton, 2016; Miettinen et al., 2015). This can help to contribute that the positive attitude towards children ('unconditional positivity') is accompanied by a desire for a long-term relationship (Schwarz \& Hassebrauck, 2007).

\section{Study 2}

Building on Study 1, Study 2 sought to validate a German language version of the same scale as in the previous study. A larger sample was recruited to test whether the lack of gender effects in Study 1 might have been the results of too little statistical power to detect such an effect. A sensitivity analysis revealed that the first study had $95 \%$ power to detect the effects of a Cohen's $d=0.55$ or larger; this number is larger even than estimates of the average effects size in psychology before bias-correction (Bakker, van Dijk, \& Wicherts, 2012). We thus deemed it advisable to aim for a larger sample in order to have a realistic chance of detecting smaller effects. Finally, the study included different additional variables to gain a better understanding of correlations, as well as potential antecedents and consequences of different attitudinal facets toward having children. In addition to standard measures of personality traits (Big Five), measures of personal upbringing experiences (attachment to mother, educational experiences), current partnerships (attachment to partner), and job and career-related scales were also included. For economic reasons, the measures from Study 1 were not surveyed again.

\section{Method}

\section{Sample}

A total of 288 participants ( 151 women, $M_{\text {age }}=24.19, S D=4.95 ; 85$ men, $M_{\text {age }}=25.16$ years, $S D=6.89$ ) were recruited from different German universities and branches of study through a mailing system. This sample size equipped the study with $95 \%$ statistical power to detect also smaller effects of a Cohen's $d=0.40$ or larger. Participation was voluntary; for the majority of participants (57\%), a university-qualifying high-school degree was the highest educational level reached. Another large cohort $(42 \%)$ had also received university degrees.

\section{Measures}

\section{German Version of the PrAttS}

A native German speaker and a native English speaker carefully translated all 13 items included in Study 1 into the German language (dual forward translation). When both translations were inconsistent, issues were discussed and resolved by consensus.

\section{Personality Factors}

The Big Five personality traits (extraversion, agreeableness, conscientiousness, neuroticism, and openness to experience) were measured on a 5-point scale using the German 50-item Big Five Personality questionnaire (Satow, 2012). 


\section{Parenting Style}

Schumacher, Stöbel-Richter, and Brähler (2002) investigated the connection between the recalled parental parenting behavior and the intensity of the wish to have a child as well as the expression of different fertility motives. It turned out that recalled parental parenting behavior, which was dismissive, over-protective and not very emotionally warm, is especially common among people who do not want to have children themselves. Persons with over-protective parents were more concerned about personal restrictions from their children and lack of support in education. In the present study, the parents' recalled parenting behavior was measured, as associations with contingent willingness (PrAttS) and anticipated annoyance (PrAttS) are assumed.

The Overprotective Education scale (Böhm, 1993) is a 34-item inventory with two subscales for overprotective education by a father or mother. Responses were recorded on a 4-point Likert scale.

\section{Attachment to Mother and Partner}

One of the most robust findings of all attachment research is the intergenerational transmission of attachment patterns (Bernier, Matte-Gagné, Bélanger, \& Whipple, 2014). van IJzendoorn (1995) conducted the first metaanalytic study of the association between maternal and child attachment. The results confirmed the robustness of the association and suggested a large effect size. Verhage and colleagues (2016) confirmed the association between maternal and child attachment in a recent meta-analysis. Securely bound children also tend to have secure bound children later on, with this secure-autonomous transmission having the greatest effect size.

Verhage and colleagues (2016) also demonstrated that dismissing caregiver attachment representation leads to avoidant caregiver attachment. It would therefore be conceivable that people with a dismissing caregiver representation have developed more defensive baby cognitions that act as a mediator to future avoidant-childattachment. The factor Anticipated Annoyance validated in study 1 could reflect this thinking. Therefore, the Specific Attachment Scale for Adults (Asendorpf et al., 1997) was used to investigate the association between attachment style and procreation attitude. The Specific Attachment Scale for Adults (Asendorpf et al., 1997) taps into respondents' attachment to their partners and mothers on secure-anxious and dependent-independent dimensions. The tool is composed of 28 items with responses recorded on a 5-point scale.

\section{Career Orientation}

The Career Management questionnaire (Gould, 1979) was included in its modified German version (Rowold, 2004) to assess two factors: career plans and job flexibility. Job and career-related scales were included because it is possible that people who prioritize career goals or job-related values devalue the idea of raising children.

\section{Results}

\section{Factor Structure: Procreation Attitude Scales}

The 13 items on the PrAttS were subjected to a confirmatory factor analysis to check whether the structure of the German version of the questionnaire differs from that of the English version. The 13 items were divided between the three latent variables, as in Study 1. Each item belonged only to one subscale. The data converged normally after 35 iterations in the data set, and the prerequisite for a confirmatory factor analysis was achieved. The confirmatory factor analysis for the PrAttS, $x^{2}(78)=975.12, p<.001$, Tucker-Lewis Index $(\mathrm{TLI})=.87$, Comparative Fit Index $(\mathrm{CFI})=.90$, Root Mean Square Error of Approximation $(\mathrm{RMSEA})=.08$, 
yielded an acceptable fit (Moosbrugger \& Kelava, 2012). Based on these results, it was assumed that all 13 manifest variables were suitable to map the latent variables and that the structure of the German version of the questionnaire is equivalent to that of the English version.

For reasons of comparability, we also conducted the same preliminary principal components analysis as in Study 1 and obtained similar results. The results revealed three components with eigenvalues greater than 1.0 that together accounted for $56.36 \%$ of the variance. Inspection of the pattern matrix and the scree plot indicated three interpretable components each containing multiple items (see Table 1). Consistent with the results obtained using the original English version of the scale, a three-dimensional structure (unconditional positivity, anticipated annoyance, and contingent willingness) was the best solution to explain the data in the sample and demonstrate that the factor structure of the German version was similar to that of the English version. These results demonstrate the robustness of the questionnaire in assessing these three constructs.

All items for each of the three scales loaded most strongly on their respective scales, with the exception of the item "Kinder sind anstrengend" (children are demanding) that loaded most strongly (negatively) on the factor unconditional positivity. Internal consistency was good (Cohen, 1988) for unconditional positivity (Cronbach's $\alpha$ $=.83$ ) and acceptable for anticipated annoyance (Cronbach's $\alpha=.69$ ) and contingent willingness (Cronbach's $\alpha$ $=.72$ ). All resulting scales proved sufficiently reliable (Table 3 ).

Table 3

Internal Consistency and Descriptive Statistics of Study 2

\begin{tabular}{|c|c|c|c|c|c|c|c|c|c|c|c|c|c|c|c|c|c|c|}
\hline \multirow[b]{2}{*}{ Variable } & \multirow[b]{2}{*}{$\alpha$} & \multirow[b]{2}{*}{ M } & \multirow[b]{2}{*}{$S D$} & \multicolumn{15}{|c|}{ Correlation (n) } \\
\hline & & & & 1 & 2 & 3 & 4 & 5 & 6 & 7 & 8 & 9 & 10 & 11 & 12 & 13 & 14 & 15 \\
\hline $\begin{array}{l}\text { 1. Unconditional } \\
\text { positivity }\end{array}$ & .83 & 3.77 & 0.82 & & & & & & & & & & & & & & & \\
\hline 2. Contingent & .69 & 3.63 & 0.75 & -.10 & & & & & & & & & & & & & & \\
\hline willingness & & & & (252) & & & & & & & & & & & & & & \\
\hline $\begin{array}{l}\text { 3. Anticipated } \\
\text { annoyance }\end{array}$ & .72 & 3.78 & 0.62 & $\begin{array}{l}-.36^{* *} \\
(250)\end{array}$ & $\begin{array}{c}.22^{* \star} \\
(250)\end{array}$ & & & & & & & & & & & & & \\
\hline 4. Neuroticism & .85 & 2.63 & 0.61 & $\begin{array}{l}-.24^{* *} \\
(191)\end{array}$ & $\begin{array}{r}-.03 \\
(191)\end{array}$ & $\begin{array}{c}.24^{\star \star} \\
(189)\end{array}$ & & & & & & & & & & & & \\
\hline 5. Agreeableness & .83 & 3.06 & 0.40 & $\begin{array}{c}.44^{* \star} \\
(191)\end{array}$ & $\begin{array}{r}-.01 \\
(191)\end{array}$ & $\begin{array}{c}.23^{\star *} \\
(189)\end{array}$ & $\begin{array}{l}-.19^{\star \star} \\
(191)\end{array}$ & & & & & & & & & & & \\
\hline 6. Conscientiousness & .69 & 2.48 & 0.41 & $\begin{array}{r}.08 \\
(190)\end{array}$ & $\begin{array}{r}.12 \\
(190)\end{array}$ & $\begin{array}{r}-.10 \\
(188)\end{array}$ & $\begin{array}{r}.08 \\
(190)\end{array}$ & $\begin{array}{c}.22^{\star \star} \\
(190)\end{array}$ & & & & & & & & & & \\
\hline $\begin{array}{l}\text { 7. Openness to } \\
\text { experience }\end{array}$ & .66 & 2.79 & 0.42 & $\begin{array}{r}.18^{\star} \\
(190)\end{array}$ & $\begin{array}{r}-.12 \\
(191)\end{array}$ & $\begin{array}{l}-.14 \\
(188)\end{array}$ & $\begin{array}{l}-.25^{\star *} \\
(190)\end{array}$ & $\begin{array}{r}.13 \\
(190)\end{array}$ & $\begin{array}{r}-.14 \\
(189)\end{array}$ & & & & & & & & & \\
\hline 8. Extraversion & .65 & 2.62 & 0.52 & $\begin{array}{l}.40^{\star \star} \\
(187)\end{array}$ & $\begin{array}{r}.08 \\
(187)\end{array}$ & $\begin{array}{r}-.13 \\
(185)\end{array}$ & $\begin{array}{l}-.32^{\star *} \\
(187)\end{array}$ & $\begin{array}{c}.33^{* \star} \\
(187)\end{array}$ & $\begin{array}{l}-.23^{* *} \\
(186)\end{array}$ & $\begin{array}{c}.31^{* *} \\
(186)\end{array}$ & & & & & & & & \\
\hline $\begin{array}{l}\text { 9. Overprotective } \\
\text { mother }\end{array}$ & .89 & 1.97 & 0.50 & $\begin{array}{r}-.13 \\
(205)\end{array}$ & $\begin{array}{r}.08 \\
(204)\end{array}$ & $\begin{array}{r}.11 \\
(203)\end{array}$ & $\begin{array}{c}.29^{\star \star} \\
(179)\end{array}$ & $\begin{array}{r}-.13 \\
(178)\end{array}$ & $\begin{array}{r}-.04 \\
(177)\end{array}$ & $\begin{array}{c}.02 \\
(177)\end{array}$ & $\begin{array}{r}-.13 \\
(174)\end{array}$ & & & & & & & \\
\hline $\begin{array}{l}\text { 10. Overprotective } \\
\text { father }\end{array}$ & .83 & 1.93 & 0.39 & $\begin{array}{r}-.06 \\
(194)\end{array}$ & $\begin{array}{r}-.13 \\
(194)\end{array}$ & $\begin{array}{r}-.01 \\
(194)\end{array}$ & $\begin{array}{r}.18^{*} \\
(180)\end{array}$ & $\begin{array}{r}-.14 \\
(180)\end{array}$ & $\begin{array}{r}-.09 \\
(179)\end{array}$ & $\begin{array}{c}.12 \\
(179)\end{array}$ & $\begin{array}{r}.03 \\
(176)\end{array}$ & $\begin{array}{c}.55^{* *} \\
(185)\end{array}$ & & & & & & \\
\hline $\begin{array}{l}\text { 11. Secure attachment } \\
\text { to mother }\end{array}$ & .85 & 4.02 & 0.87 & $\begin{array}{c}.28^{* *} \\
(194)\end{array}$ & $\begin{array}{r}.14 \\
(194)\end{array}$ & $\begin{array}{r}-.14 \\
(192)\end{array}$ & $\begin{array}{l}-.32^{\star \star} \\
(187)\end{array}$ & $\begin{array}{c}.28^{\star *} \\
(187)\end{array}$ & $\begin{array}{r}.13 \\
(186)\end{array}$ & $\begin{array}{r}.15^{\star} \\
(186)\end{array}$ & $\begin{array}{c}.27^{\star *} \\
(183)\end{array}$ & $\begin{array}{l}-.41^{* *} \\
(181)\end{array}$ & $\begin{array}{c}-.18^{*} \\
(183)\end{array}$ & & & & & \\
\hline $\begin{array}{l}\text { 12. Dependent } \\
\text { attachment to mother }\end{array}$ & .84 & 3.66 & 0.39 & $\begin{array}{c}.67^{* \star} \\
(249)\end{array}$ & $\begin{array}{l}.29^{* *} \\
(248)\end{array}$ & $\begin{array}{l}.23^{* \star} \\
(249)\end{array}$ & $\begin{array}{r}.00 \\
(187)\end{array}$ & $\begin{array}{c}.26^{* \star} \\
(187)\end{array}$ & $\begin{array}{r}.01 \\
(186)\end{array}$ & $\begin{array}{c}.05 \\
(186)\end{array}$ & $\begin{array}{c}.36^{* \star} \\
(183)\end{array}$ & $\begin{array}{l}-.11 \\
(202)\end{array}$ & $\begin{array}{c}-.16^{*} \\
(193)\end{array}$ & $\begin{array}{l}.23^{\star \star} \\
(190)\end{array}$ & & & & \\
\hline
\end{tabular}




\begin{tabular}{|c|c|c|c|c|c|c|c|c|c|c|c|c|c|c|c|c|c|c|}
\hline \multirow[b]{2}{*}{ Variable } & \multirow[b]{2}{*}{$\alpha$} & \multirow[b]{2}{*}{$M$} & \multirow[b]{2}{*}{$S D$} & \multicolumn{15}{|c|}{ Correlation $(n)$} \\
\hline & & & & 1 & 2 & 3 & 4 & 5 & 6 & 7 & 8 & 9 & 10 & 11 & 12 & 13 & 14 & 15 \\
\hline $\begin{array}{l}\text { 13. Secure attachment } \\
\text { to partner }\end{array}$ & .82 & 4.10 & 0.71 & $\begin{array}{r}.19^{*} \\
(156)\end{array}$ & $\begin{array}{r}.15 \\
(156)\end{array}$ & $\begin{array}{r}-.09 \\
(155)\end{array}$ & $\begin{array}{l}-.26^{* *} \\
(154)\end{array}$ & $\begin{array}{r}.15 \\
(154)\end{array}$ & $\begin{array}{l}-.15 \\
(154)\end{array}$ & $\begin{array}{r}.12 \\
(153)\end{array}$ & $\begin{array}{c}.24^{\star \star} \\
(150)\end{array}$ & $\begin{array}{l}-.15 \\
(146)\end{array}$ & $\begin{array}{r}-.09 \\
(150)\end{array}$ & $\begin{array}{l}.24^{\star *} \\
(151)\end{array}$ & $\begin{array}{r}.13 \\
(154)\end{array}$ & & & \\
\hline $\begin{array}{l}\text { 14. Dependent } \\
\text { attachment to partner }\end{array}$ & .80 & 2.84 & 0.66 & $\begin{array}{r}.14 \\
(158)\end{array}$ & $\begin{array}{l}.29^{* *} \\
(158)\end{array}$ & $\begin{array}{r}.08 \\
(157)\end{array}$ & $\begin{array}{r}.21 \\
(156)\end{array}$ & $\begin{array}{r}-.05 \\
(156)\end{array}$ & $\begin{array}{r}.07 \\
(156)\end{array}$ & $\begin{array}{l}-.20^{*} \\
(155)\end{array}$ & $\begin{array}{r}.00 \\
(152)\end{array}$ & $\begin{array}{r}.03 \\
(148)\end{array}$ & $\begin{array}{r}-.10 \\
(152)\end{array}$ & $\begin{array}{l}-.10 \\
(153)\end{array}$ & $\begin{array}{l}.28^{\star \star} \\
(156)\end{array}$ & $\begin{array}{l}.32^{\star *} \\
(157)\end{array}$ & & \\
\hline 15. Career plans & .87 & 3.26 & 0.84 & $\begin{array}{r}.15^{*} \\
(241)\end{array}$ & $\begin{array}{l}.17^{\star *} \\
(241)\end{array}$ & $\begin{array}{l}-.07 \\
(239)\end{array}$ & $\begin{array}{r}-.09 \\
(187)\end{array}$ & $\begin{array}{r}.07 \\
(187)\end{array}$ & $\begin{array}{l}.25^{\star *} \\
(186)\end{array}$ & $\begin{array}{r}.15^{\star} \\
(186)\end{array}$ & $\begin{array}{r}.02 \\
(184)\end{array}$ & $\begin{array}{r}.09 \\
(200)\end{array}$ & $\begin{array}{r}-.00 \\
(190)\end{array}$ & $\begin{array}{r}.09 \\
(191)\end{array}$ & $\begin{array}{r}.16 \\
(237)\end{array}$ & $\begin{array}{r}.12 \\
(152)\end{array}$ & $\begin{array}{r}.06 \\
(154)\end{array}$ & \\
\hline 16. Job flexibility & .56 & 3.51 & 0.74 & $\begin{array}{c}.23^{\star *} \\
(243)\end{array}$ & $\begin{array}{c}-.13^{*} \\
(243)\end{array}$ & $\begin{array}{r}-.09 \\
(241)\end{array}$ & $\begin{array}{l}-.32^{\star *} \\
(190)\end{array}$ & $\begin{array}{c}.27^{\star *} \\
(190)\end{array}$ & $\begin{array}{r}-.05 \\
(189)\end{array}$ & $\begin{array}{c}.47^{\star *} \\
(189)\end{array}$ & $\begin{array}{c}.25^{\star \star} \\
(186)\end{array}$ & $\begin{array}{r}-.12 \\
(203)\end{array}$ & $\begin{array}{r}.09 \\
(193)\end{array}$ & $\begin{array}{r}.14 \\
(193)\end{array}$ & $\begin{array}{r}.08 \\
(239)\end{array}$ & $\begin{array}{r}-.03 \\
(156)\end{array}$ & $\begin{array}{r}-.06 \\
(158)\end{array}$ & $\begin{array}{r}.10 \\
\text { (239) }\end{array}$ \\
\hline
\end{tabular}

As found in Study 1 and as expected, women $(M=3.91, S D=0.75)$ demonstrated a higher unconditional positivity than men $(M=3.54, S D=0.90, t(249)=-3.48, p<.001$, Cohen's $d=0.45$. An opposite effect was found with the items concerning the hesitation to have children. Men $(M=3.81, S D=0.75)$ had a higher degree of contingent willingness than women $(M=3.55, S D=0.71, t(249)=-2.74, p<.007$, Cohen $d=0.36)$.

\section{Exploratory Interrelations}

We explored the relation of the PrAttS with the 50-item Big Five Inventory. There were a number of personality correlates of the PrAttS scales, most notably Unconditional Positivity was related to high levels of extraversion and agreeableness, whereas Anticipated Annoyance corresponded with neuroticism (Table 3).

Potentially even more relevant were the associations between the PrAttS and attachment type. Unconditional positivity was significantly correlated with a secure attachment to mother and father. Dependent attachment to one's mother had a strong positive relationship with unconditional positivity. Interestingly, contingent willingness had a moderate positive relationship with a dependent attachment to both one's mother and father. Anticipated annoyance was moderately correlated with dependent attachment to one's mother.

All career management indices were significantly related with unconditional positivity and contingent willingness. Career plans and job flexibility had moderate positive relationships with unconditional positivity and moderate positive relationships with contingent willingness. Career plans and job flexibility had negative relationships with job flexibility. According to the results, the PrAttS scores were only marginally correlated with the education styles of participants' parents (Table 3).

\section{Discussion}

Study 2 confirmed the three-dimensional structure (unconditional positivity, anticipated annoyance, and contingent willingness) for the German version of the scale. The internal consistency of the three dimensions was lower in the German than in the English version, but the indices were judged to be satisfactory because both indices were on the high end of the a values usually deemed acceptable or good (between 0.72 and 0.83 ; Cohen, 1988).

We explored the relation of the three dimensions of the PrAttS against conceptually related variables. Unconditional positivity had a moderate positive relationship with extraversion and agreeableness as well as a modest relationship with openness. In contrast, a high level of neuroticism had a moderate negative correlation with unconditional positivity, and unconditional positivity was significantly correlated with a secure attachment to 
one's mother and the father. Career plans and job flexibility had positive relationships with unconditional positivity, indicating that considerable mental flexibility and detailed thoughts about the future can be found in people with welcoming attitudes about babies. It can be concluded that, in general, positive qualities are associated with a positive attitude toward children.

Contingent willingness was positively related to dependent attachment to both one's mother and father. Correspondingly, job flexibility was negatively associated with contingent willingness, while clear and detailed career plans were positively related to contingent willingness. The data analysis revealed that contingent willingness is independent of education style of participants' parents. It can be concluded that high contingent willingness is reflected in participants' relationships with their parents as well as their job cognitions.

\section{General Discussion}

The current paper presented two studies of the validation of a multilingual (English and German) questionnaire regarding attitudes towards procreation. The studies reported the development and initial validation of a new self-reporting questionnaire (Study 1) as well as the psychometric evaluation and construct validation of the German version of the questionnaire (Study 2). Specifically, the PrAttS consists of 13 items representing three underlying dimensions: (1) unconditional positivity, (2) anticipated annoyance and (3) contingent willingness. The PrAttS provides an explicit method of interest for children, providing an alternative to more recently criticized implicit measures. Some of our exploratory found factors can be classified as part of the wanting-liking paradigm (Dai, Brendl, \& Ariely 2010).

In line with Parsons and colleagues (2011), the current paper showed twice a gender difference in emotional attitudes ('liking'), revealing that women have a stronger emotional interest in procreation and babies. However, the current paper also showed twice that this gender difference disappears when the motivational attitude to procreation and babies was measured. These results show that attitudes toward babies are multifaceted and that supposedly reliable gender differences (Hildebrandt \& Fitzgerald, 1978) are less reliable than commonly thought.

The current studies have some limitations. First, the samples had a limited age range, with few older people included. As a result, generalizability in relation to older age groups should be verified. According to Jansen and Liefbroer (2006), understanding the motivations of only one partner is not enough to understand the decision for and against children, so that in future investigations, it would also make sense to survey attitudes towards babies in couples. Additionally, the construct validity data relied solely on self-reported dimensional questionnaires. Other methods such as reports by other informants or observational data of attachment behaviors would be useful in further studies.

The developed instrument provides an economic tool for future research. The scale could be employed both at the level of individual data to seek how mating preferences are associated with attitudes towards procreation and which weight they have. Arguably, even more relevant, future dyadic studies could delineate how similarity of procreation attitudes affects relationship satisfaction. Although the general principle that similarity breeds liking (Alves, Koch, \& Unkelbach, 2016; Byrne, 1971) has received only moderate support in its extension that partner-similarity in personality is associated with relationship success (Lykken \& Tellegen, 1993; Robins, Caspi, \& Moffitt, 2000), having offspring is arguably a relevant common relationship goal for many people. 
Intra-relational consensus on whether one feels positive, hesitant or negative towards having babies is thus likely to be a determinant not only of relationship satisfaction but also stability, particularly in the biographical phases during which having babies is part of a cultural script.

In conclusion, the PrAttS represents a multidimensional yet concise measure of attitudes toward procreation, with strong internal consistency and some clear interrelations. Because of its length, the PrAttS can be viewed as an economical tool to assess attitudes toward procreation in a wide range of fields such as family counselling or dating services.

\section{Funding}

The authors have no funding to report.

\section{Competing Interests}

The authors have declared that no competing interests exist.

\section{Acknowledgments}

The authors have no support to report.

\section{Author Note}

The work presented here is part of a PhD thesis (Marhenke, 2019). The primary researcher is Tristan Marhenke, and the supervisor is Prof. Dr. Roland Imhoff.

\section{Data Availability}

Data for this article is freely available (see the Supplementary Materials section).

\section{Supplementary Materials}

The questionnaires used, raw data sets and aggregated data sets for both studies are available via https://osf.io/tkp7v.

\section{Index of Supplementary Materials}

Marhenke, T., \& Imhoff, R. (2020). Supplementary materials to: Different facets of attitudes towards having children: The Procreation Attitude Scale (PrAttS) [Raw data, Aggregated data, Questionnaires]. OSF. https://osf.io/tkp7v

\section{References}

Alves, H., Koch, A., \& Unkelbach, C. (2016). My friends are all alike-the relation between liking and perceived similarity in person perception. Journal of Experimental Social Psychology, 62, 103-117. https://doi.org/10.1016/j.jesp.2015.10.011

Asendorpf, J. B., Banse, R., Wilpers, S., \& Neyer, F. J. (1997). Beziehungsspezifische Bindungsskalen für Erwachsene und ihre Validierung durch Netzwerk und Tagebuchverfahren. Diagnostica, 43, 289-313.

Bakker, M., van Dijk, A., \& Wicherts, J. M. (2012). The rules of the game called psychological science. Perspectives on Psychological Science, 7(6), 543-554. https://doi.org/10.1177/1745691612459060 
Bauer, G., \& Kneip, T. (2013). Fertility from a couple perspective: A test of competing decision rules on proceptive behaviour. European Sociological Review, 29, 535-548. https://doi.org/10.1093/esr/jcr095

Berman, P. W. (1980). Are women more responsive than men to the young? A review of developmental and situational variables. Psychological Bulletin, 88, 668-695. https://doi.org/10.1037/0033-2909.88.3.668

Bernier, A., Matte-Gagné, C., Bélanger, M.-E., \& Whipple, N. (2014). Taking stock of two decades of attachment transmission gap: Broadening the assessment of maternal behavior. Child Development, 85(5), 1852-1865. https://doi.org/10.1111/cdev.12236

Böhm, B. (1993). Familiäre Ursachen von Bulimie [Unpublished master's thesis]. Universität Regensburg, Regensburg, Germany.

Byrne, D. (1971). The attraction paradigm. New York, NY, USA: Academic Press.

Cohen, J. (1988). Statistical power analysis for the behavioral sciences. Hillsdale, NJ, USA: Erlbaum.

Dai, X., Brendl, C. M., \& Ariely, D. (2010). Wanting, liking, and preference construction. Emotion, 10(3), 324-334. https://doi.org/10.1037/a0017987

Fiore, A. T., \& Donath, J. S. (2005). Homophily in online dating: When do you like someone like yourself? Computer-Human Interaction, 1371-1374. https://doi.org/10.1145/1056808.1056919

Gould, S. (1979). Characteristics of career planners in upwardly mobile occupations. Academy of Management Journal, 22, 539-550.

Hildebrandt, K. A., \& Fitzgerald, H. E. (1978). Adults' responses to infants varying in perceived cuteness. Behavioural Processes, 3, 159-172. https://doi.org/10.1016/0376-6357(78)90042-6

Hutteman, R., Bleidorn, W., Penke, L., \& Denissen, J. (2013). It takes two: A longitudinal dyadic study on predictors of fertility outcomes. Journal of Personality, 81, 487-498. https://doi.org/10.1111/jopy.12006

Imhoff, R., Schmidt, A. F., Nordsiek, U., Luzar, C., Young, A. W., \& Banse, R. (2010). Viewing time revisited: Prolonged response latencies for sexually attractive targets under restricted conditions. Archives of Sexual Behavior, 39, 1275-1288. https://doi.org/10.1007/s10508-009-9595-2

Imhoff, R., Schmidt, A. F., Weiß, S., Young, A. W., \& Banse, R. (2012). Vicarious viewing time: Prolonged response latencies for sexually attractive targets as a function of task- or stimulus-specific processing. Archives of Sexual Behavior, 41, 1389-1401. https://doi.org/10.1007/s10508-011-9879-1

Jansen, M., \& Liefbroer, A. (2006). Couple's attitudes, childbirth, and the division of labor. Journal of Family Issues, 27, 1487-1511. https://doi.org/10.1177/0192513X06291038

Katz-Wise, S. L., Priess, H., \& Hyde, J. (2010). Gender-role attitudes and behaviour across the transition to parenthood. Developmental Psychology, 46, 18-28. https://doi.org/10.1037/a0017820

Kaufman, G., \& Uhlenberg, P. (2000). The influence of parenthood on work effort of married men and women. Social Forces, 78, 931-947. https://doi.org/10.2307/3005936

Lichtenstein, S., \& Slovic, P. (2006). The Construction of Preference. London, United Kingdom: Cambridge University Press. 
Liefbroer, A. (2005). The impact of perceived costs and rewards of childbearing on entry into parenthood: Evidence from a panel study. European Journal of Population, 21, 367-391. https://doi.org/10.1007/s10680-005-2610-y

Liu, S., Xiao, N. G., Quinn, P. C., Zhu, D., Ge, L., Pascalis, O., \& Lee, K. (2015). Asian infants show preference for own-race but not other-race female faces: The role of infant caregiving arrangements. Frontiers in Psychology, 6, Article 593. https://doi.org/10.3389/fpsyg.2015.00593

Lykken, D. T., \& Tellegen, A. (1993). Is human mating adventitious or the result of lawful choice? A twin study of mate selection. Journal of Personality and Social Psychology, 65, 56-68. https://doi.org/10.1037/0022-3514.65.1.56

Marhenke, T. (2019). Attitudes towards babies: Social influences and gender differences in the context of baby attitudes [Doctoral dissertation, University of Cologne, Cologne, Germany]. Retrieved from http://kups.ub.uni-koeln.de/id/eprint/9403

Mathews, T. J., \& Hamilton, B. E. (2016). Mean age of mothers is on the rise: United States, 2000-2014. NCHS Data Brief, $232,1-8$.

Matias, M., \& Fontaine, A. M. (2012). Can we have it all? The work and-family coping profiles of dual-earners. Family Science, 3, 255-265. https://doi.org/10.1080/19424620.2012.723220

Miettinen, A., Rotkirch, A., Szalma, I., Donno, A., \& Tanturri, M. L. (2015). Increasing childlessness in Europe: Time trends and country differences. (Families and Societies, Working Paper No. 33). Retrieved from http://www.familiesandsocieties.eu/wp-content/uploads/2015/03/WP33MiettinenEtAl2015.pdf

Moosbrugger, H., \& Kelava, A. (2012). Testtheorie und Fragebogenkonstruktion (2nd ed.). Berlin, Germany: Springer.

O'Laughlin, E., \& Anderson, V. (2001). Perceptions of parenthood among young adults: Implications for career and family planning. The American Journal of Family Therapy, 29, 95-108. https://doi.org/10.1080/01926180125728

Parsons, C. E., Young, K. S., Kumari, N., Stein, A., \& Kringelbach, M. L. (2011). The motivational salience of infant faces is similar for men and women. PLOS ONE, 6(5), Article e20632. https://doi.org/10.1371/journal.pone.0020632

Penke, L., \& Asendorpf, J. B. (2008). Beyond global sociosexual orientations: A more differentiated look at sociosexuality and its effects on courtship and romantic relationships. Journal of Personality and Social Psychology, 95, 1113-1135. https://doi.org/10.1037/0022-3514.95.5.1113

Petterson, L. J., Dixson, B. J., Little, A. C., \& Vasey, P. L. (2018). Viewing time and self-report measures of sexual attraction in Samoan cisgender and transgender androphilic males. Archives of Sexual Behavior, 47, 2427-2434. https://doi.org/10.1007/s10508-018-1267-7

Robins, R. W., Caspi, A., \& Moffitt, T. E. (2000). Two personalities, one relationship: Both partners' personality traits shape the quality of their relationship. Journal of Personality and Social Psychology, 79, 251-259.

https://doi.org/10.1037/0022-3514.79.2.251

Rosenzweig, S. (1942). The photoscope as an objective device for evaluating sexual interest. Psychosomatic Medicine, 4 , 150-158. https://doi.org/10.1097/00006842-194204000-00004

Rowold, J. (2004). Karriereplanung [Deutsche Übersetzung des Fragebogens zur Karriereplanung von Gould, 1979]. Münster, Germany: Westfälische Wilhelms-Universität, Psychologisches Institut II. 
Satow, L. (2012). Big-Five-Persönlichkeitstest (B5T): Test- und Skalendokumentation. Retrieved from http://www.drsatow.de

Schmidt, A. F., Babchishin, K. M., \& Lehmann, R. J. B. (2017). A meta-analysis of viewing time measures of sexual interest in children. Archives of Sexual Behavior, 46, 287-300. https://doi.org/10.1007/s10508-016-0806-3

Schumacher, J., Stöbel-Richter, Y., \& Brähler, E. (2002). Recalled parental rearing and the wish to have a child - Are there Associations? Psychother Psychosom Med Psychol, 52(7), 314-322. https://doi.org/10.1055/s-2002-32864

Schwarz, S., \& Hassebrauck, M. (2007). Interindividuelle Unterschiede in Beziehungspräferenzen: Das Konstrukt Beziehungsorientierung (BZO) und seine Messung. Zeitschrift für Sozialpsychologie, 38, 179-193. https://doi.org/10.1024/0044-3514.38.3.179

van IJzendoorn, M. H. (1995). Adult attachment representations, parental responsiveness, and infant attachment: A metaanalysis on the predictive validity of the Adult Attachment Interview. Psychological Bulletin, 117, 387-403.

https://doi.org/10.1037/0033-2909.117.3.387

Verhage, M. L., Schuengel, C., Madigan, S., Fearon, R. M. P., Oosterman, M., Cassibba, R., \& van IJzendoorn, M. H. (2016). Narrowing the transmission gap: A synthesis of three decades of research on intergenerational transmission of attachment. Psychological Bulletin, 142(4), 337-366. https://doi.org/10.1037/bul0000038

\section{Appendix}

\section{Complete list of items}

1. I am afraid of bringing a child into this world.

2. I feel I am capable of looking after a child.

3. An unplanned pregnancy is a disaster.

4. I feel at ease in the presence of children.

5. Children require more love than I can give.

6. I feel happy when I see children playing.

7. Screaming infants make me feel uneasy.

8. I'd be a good father / mother.

9. I can see myself having more than one child.

10. Raising a child on your own is horrible.

11. To have a disabled child is the worst thing that can happen.

12. For me, having a child means to be loved.

13. I'd quickly learn to change nappies.

14. I feel safe surrounded by my family.

15. Having children is hardly affordable.

16. Children are demanding.

17. Children require a lot of attention.

18. You must do without many freedoms when you have a child.

19. Bringing up children is difficult.

20. Having a baby means less time for myself.

21. You should only have children when you have a secure job.

22. You live on through your children.

23. I am myself responsible for contraception.

24. Many children have accidents.

25. If you have a child, you need a partner who you can rely on. 
26. Having children is a way of achieving self-fulfillment.

27. It's easy to travel with a baby.

28. Having children raises self-esteem.

29. You can't have a career when you have a child.

30. You should only have children with someone who you have known for years.

31. You should only have children once you've found the perfect partner.

32. I would never have unprotected sexual intercourse.

33. If I / my partner were to become pregnant, I know people who could support us.

34. I'd work as a babysitter if paid adequately.

35. Having children is sufficiently supported by the state.

36. Children often become ill. 